\title{
Vita ŽLENDER
}

\section{Developing a spatially explicit method for delineating peri-urban landscape}

The ill-defined space between urban and rural areas is typically referred to as peri-urban landscape. One key reason for this lack of clarity is the unduly broad scale of conceptual and geographical resolution. This article focuses on its spatial elucidation at a sub-regional scale. It describes a method for delineating peri-urban landscape, based on spatial and demographic criteria. Arguably, spatially explicitly denoted peri-urban landscape on a sub-regional level would help in choosing appropriate local and region- al planning approaches and policies for its development. The method, based on an overlay analysis, was tested using datasets from regional and municipal authorities in Ljubljana and Edinburgh. The results indicate that this less ambiguous spatial definition of peri-urban landscape offers a sound basis for planning and policy development.

Keywords: peri-urban landscape, overlay method, Ljubljana, Edinburgh, landscape planning, GIS 


\section{Introduction}

Although peri-urbanization is not a new phenomenon, it has attracted increasing attention in recent years from landscape and urban planners, geographers, and others. The outcome of peri-urbanization is a spatial type that early studies mainly linked to urban sprawl, but these spaces are now thought to share particular characteristics as the interface for rural and urban interactions and mixes (Meeus \& Gulinck, 2008; La Rosa et al., 2018; Shaw et al., 2020). This kind of space has been variously characterized as peri-urban, urban fringe, suburban area, or urban periphery, but despite a growing number of studies, the definition remain unclear in conceptual and spatial terms (Gonçalves et al., 2017). These conceptual issues have been discussed elsewhere (see Žlender \& Gemin, 2020; Žlender, 2021); for present purposes, we employ the term peri-urban landscape and define peri-urban areas as mixed land-use territories within that landscape (Žlender, 2021).

The focus of this study is to elucidate the spatial character of peri-urban landscape. In geographic terms, peri-urban landscapes are characterized by a higher population density than rural areas and are likely to be affected by urban sprawl (Couch et al., 2008; Jacquin et al., 2008; Piorr et al., 2011; Maleas, 2018). These areas typically attract industrial hubs and tertiary sector structures like outlets, shopping malls, technology and logistics centres (Couch et al., 2008; Gant et al., 2011; Gonçalves et al., 2017; Martyniuk-Pęczek et al., 2017), with an accompanying decline in rural uses like agriculture or forestry. Vacant land and protected natural habitats are also likely to be found in peri-urban areas. To date, research on peri-urban landscapes has ranged from analyses of land use patterns (Jacquin et al., 2008; van Vliet et al., 2019) to integrated analyses of multiple dimensions such as population and economic flows, and mobility patterns (see Mortoja et al., 2020, for a review).

While these integrated approaches attempt to provide a holistic view of spatial organization, land use and other dimensions (Gonçalves et al., 2017), the spatial characteristics of peri-urban landscapes can be very varied, and any analysis of peri-urban dynamics must take account of this diversity (Piorr et al., 2011). In particular, standard planning definitions must incorporate spatial analysis of land use patterns, appropriate scaling of spatial indices, and clear delineation to support spatial planning and policy implementation, especially when projecting urban growth boundaries to limit any undesirable effects of urban expansion (Inostroza et al., 2013; Wandl et al., 2014; Mortoja et al., 2020).

To that end, the present study advances a spatially explicit method of analysis to define the spatial extent of peri-urban landscape and to classify peri-urban areas. As peri-urban landscape delineation at the regional scale has proved insufficiently precise, the proposed approach focuses on the sub-regional scale. The study addresses two main research questions.

RQ1: What and where are the boundaries of peri-urban landscape?

RQ2: Given the diversity of peri-urban land uses, morphological characteristics, and economic and cultural processes, is a more precise delineation possible or even necessary?

This study describes a spatially explicit method for delineating peri-urban landscapes to guide more appropriate approaches to planning. Specifically, the objectives were (1) to propose an operational methodology to delineate peri-urban landscapes; (2) to select and assess datasets for analysis; (3) to evaluate the results in the context of the relevant literature; and (4) to suggest directions for future planning and policy development. While delineation seems possible, the quality and quantity of available data may be problematic, especially in terms of granularity, spatial extent, accuracy, and differences in approaches to land use classification. We discuss whether less ambiguous spatial delineation of peri-urban landscapes would enhance planning and development, and we suggest how the study findings might improve current planning practice.

The proposed approach was first developed and implemented as part of a wider study (Žlender, 2014) and it has since been updated using more recent datasets for the test areas in the case cities of Ljubljana and Edinburgh. These two cities were selected as representative of the medium-sized cities in which most Europeans live (Giffinger et al., 2007), and for pragmatic reasons (e.g., access to databases and no language barriers for the researchers). The rest of the article is organized as follows. In Section 2, we define the study context, reviewing existing typologies to identify classification variables and spatial units of analysis and selecting the most appropriate typology for peri-urban delineation. In Section 3, we describe how we studied land use and other geographical aspects of the peri-urban landscape in both cities and outline the characteristics of the data and methodology used for delineation. The results of the analyses are discussed in Section 4. Finally, in Section 5, we evaluate the proposed method as a support tool for peri-urban planning and policy development on the basis of the case study results.

\section{Characterizing and classifying peri- -urban landscapes: Literature review}

Among the changes caused by ongoing urbanization, some peri-urban areas can no longer be clearly or easily defined as urban or rural, as rapid urban growth continues to consume 
agricultural land for residential and economic purposes (Cattivelli, 2021a). In the late 1980s, this undefined land, which we characterize as peri-urban landscape, was recognized as a distinct spatial type for research purposes, if not in planning practice. It was further suggested that such areas constitute a link rather than a divide between rural and urban (Unwin, 1989; Adell, 1999) as a transitional space characterized by rapid change, complexity, intrinsic variability (especially in spatial organization and land use concentration) and blurred boundaries (Gant et al., 2011; Piorr et al., 2011; Gonçalves et al., 2017; Mortoja et al., 2020), often extending beyond administrative boundaries (Iaquinta \& Drescher, 2000; Rauws $\&$ de Roo, 2011). As this vague geographical identity can also lead to tenure-related conflicts (Dadashpoor \& Ahani, 2019), it has been argued that clearer delineation of such territories is needed to facilitate better governance (Cattivelli, 2021b). In the extensive body of research investigating the rural-urban relationship and the nature of the peri-urban, most scholars have relied on spatial perspectives (e.g., land use) to delineate this landscape and its limits (Gonçalves et al., 2017); some of these analyses have incorporated other factors such as socio-demographics. For example, the PLUREL project defined the peri-urban area in terms of an urban fringe (a zone along the edges of a built-up area, with scattered lower density settlement, transport hubs and large green open spaces) and an urban periphery (smaller settlements of lower population density, industrial areas and other urban land uses surrounding the main built-up areas) (Piorr et al., 2011).

Additionally, the various regional typologies developed at the pan-European level have typically employed variables like population density of built-up areas, population size, morphology of mixed (built and open) spaces, infrastructure characteristics (e.g. accessibility), mix of functions at the regional scale, economic diversification, rate of urbanization, administrative boundaries, and distance to urban centres (Iaquinta \& Drescher, 2000; ESPON, 2005; Korcelli, 2008; Perpar, 2009; Dijkstra \& Poelman, 2010; OECD, 2010; Piorr et al., 2011; Internet 1). In an overview of 80 classification methods developed by statistical offices, national governments and scholars over the last two decades in Europe, Cattivelli (2021b) identified five distinct methods in terms of their defining variables: demographic dynamics, economic and social indicators, settlement structure, distance and hybrid. However, not all of these variables are easy (or even possible) to map. Among the studies reviewed, demographic census data, land cover data and administrative boundaries proved to be the most useful variables for mapping peri-urban landscape (Iaquinta \& Drescher, 2000; Piorr et al., 2011; Wandl et al., 2014), and these inform our analysis here. Finally, while most of these approaches adopt a regional scale, this is sometimes narrowed to the metropolitan or sub-regional level, and some have identified this as the most appropriate scale at which to address rural and urban dynamics (Piorr et al., 2011).

\section{Methodology and analysis}

\subsection{Research approach}

The classification variables and spatial units identified in the literature review helped determine the most appropriate typology for delineating the peri-urban landscape. On that basis, we devised a new methodology that builds on the understanding that this is not simply a gradient between urban and rural but refers to interconnected territories independent of administrative boundaries. The analysis of rural-urban territories in different cultural and topographic settings is based on the identification of general peri-urban land use types and overlay analysis as described below.

\subsection{Identification of peri-urban land use types}

The existing literature suggests that peri-urban boundaries cannot be defined in terms of particular land use characteristics such as discontinuous land use (Mortoja et al., 2020) but must take account of multiple factors as discussed above (Gonçalves et al., 2017). As some of these are difficult or impossible to map, we defined five general peri-urban land use types based on readily available information rather than new data to simplify the procedure for future users. This typology drew on existing concepts to describe the character and limits of peri-urban areas (see Section 2). Land use categories were assigned to each type in line with the general European Union approach to spatial development, which stresses the importance of conserving the landscape to halt the loss of biodiversity, cultural identity and ecosystem services associated with future land take, helping improve soil functions and sustain landscape quality (Committee on Spatial Development, 1999; Council of Europe, 2000; European Commission, 2011; EU, 2011). We also incorporated perceptual factors on the basis of previous evidence that local inhabitants regard some built structures (e.g. commercial and logistic centres, transport hubs, dumps, housing areas) as unattractive while semi-natural green spaces, open recreational areas, parks and similar are perceived as attractive (Žlender, 2021). Finally, it should be stressed that the data are determined by availability and so change from case to case; while the datasets used here relate specifically to the two case cities, we identified the following five general peri-urban land use types.

- Areas of residential-scale agriculture and leisure uses (ARSALU): land uses that are managed formally, semi-formally or not at all and support utility and leisure uses. These include city (urban) farms, allotments, community 
gardens, private gardens, residential amenity green space, churchyards and cemeteries.

- Areas of industrial-scale agriculture and other monofunctional uses (AIAMU): agricultural and other areas that are large in scale and are used intensively or unsustainably. These include primary and secondary agricultural land, vineyards, orchards and forest nurseries. Golf courses also fall into this category because they involve intensive care that is often linked to environmental issues like herbicide pollution, soil erosion and biodiversity decline. These issues may be more pressing in continental Europe, as seasonal climatic variations entail higher maintenance demands.

- Sealed land, wastelands, industrial and brownfield sites with accompanying infrastructure (SWIBS): built-up and poor quality land, including degraded landscapes, land with little or no vegetation cover, abandoned sand and gravel pits, quarries, industrial and business sites, special economic areas, areas of scattered development, infertile, derelict and vacant land, environmental infrastructure, landfill sites, degraded urban areas, dams, boatyards, drains, weirs, docks, lock-gates, ditches and proposed housing areas.

- Cultural and amenity landscapes (CAL): larger semi-natural open spaces, parks and other managed green spaces, including country parks, regional parks, local parks, nature parks, historical parks and squares, informal recreation areas, tourism areas and green spaces, sport and recreation areas, playgrounds, linear green spaces, tree belts and woodlands, river and canal banks, semi-natural open spaces, special-purpose forests, forest reserves, nature reserves, ecologically important areas, Natura 2000 protected areas, grassland, pastures and marshland.

- Protected natural areas for active and solitary recreation (PA): national parks and other wilderness environments. (This type was not found in either of the case cities.)

\subsection{Assessment of spatial datasets}

Having identified these general peri-urban land use types, the relevant datasets were acquired from the city council and other government offices and were assigned to the land use types defined in Section 3.2. The relevant data were transformed for use in a GIS environment, where they were overlaid and merged into clusters corresponding to the above types to produce a graphical representation of general land use types.

Population densities from census databases (Internet 2; SURS, 2019) and data for peri-urban areas acquired from local spatial plans and/or other formal documents were also overlaid with data derived from the clusters of general peri-urban land use types. In Ljubljana, population densities referred to settle- ments in the Municipality of Ljubljana and all neighbouring municipalities. In Edinburgh, these data referred to postcodes in the municipality and neighbouring municipalities. Formal designation of peri-urban areas in Ljubljana was based on the Municipal Spatial Plan (OPN; Odlok o občinskem, 2010), which defines the following settlements as peri-urban: Šentvid, Polje with Novo Polje and Črnuče, Pržan, Kamna Gorica, Podutik, Gunclje, Stanežiče, Medno, Brod, Tomačevo, Ježa and Podgorica, Vevče, Kašelj, Zalog, settlements west of the city bypass near the Polhov Gradec Hills, Šmartno, Gameljne, Bizovik, Spodnja Hrušica, Sostro, settlements along the Ižanska Cesta and Črna Vas. In Edinburgh, the designated areas were based on the Local Development Plan (LDP; CEC, 2016) areas other than designated "urban areas" (i.e., Green Belt and Countryside Policy areas).

\subsection{Overlay method}

The overlay method combines data or information from several datasets to derive new information that integrates spatial data with attribute data (which may be weighted). Input criteria can be transformed in various ways, including weighted overlay, spatial joins, cross tabulation, editing layers with clipping intersection, or union (ESRI, 2021). Overlay analysis is traditionally used in suitability modelling, but it has also been used to define spatial units - for instance, in landscape regionalization (Dang et al., 2000; Stahlschmidt et al., 2017) or to specify landscape types in landscape character assessment (Swanwick, 2002).

The weighted overlay method was used here to delineate the peri-urban landscape in both case cities; criteria were differently weighted to distinguish between the urban periphery and urban fringe (see Section 2). All mapping was performed in a GIS environment using a combination of two computer software programs; vector data were prepared, adjusted and cleaned in ArcMap 9.2 for import to ProVal 2000 (ONIX, 2000) to be rasterized (homogeneous spatial units of 10 by $10 \mathrm{~m}$ ) and weighted for final cartographic representation. The overlaid datasets yielded specific spatial patterns that were then compared with aerial images from Google Earth to assess whether the urban fringe and urban periphery exhibited the spatial properties described in the literature. On that basis, the peri-urban landscape was manually delineated as the sum of the urban fringe and urban periphery.

The data overlaying procedure involved the following steps. First, we defined the characteristic features of urban fringe and urban periphery to derive an evaluation scale for the purpose of delineation. Peri-urban landscape has been characterized as a mix of low-value land combining landfill and brownfield sites, wasteland and semi-natural green open spaces that people 


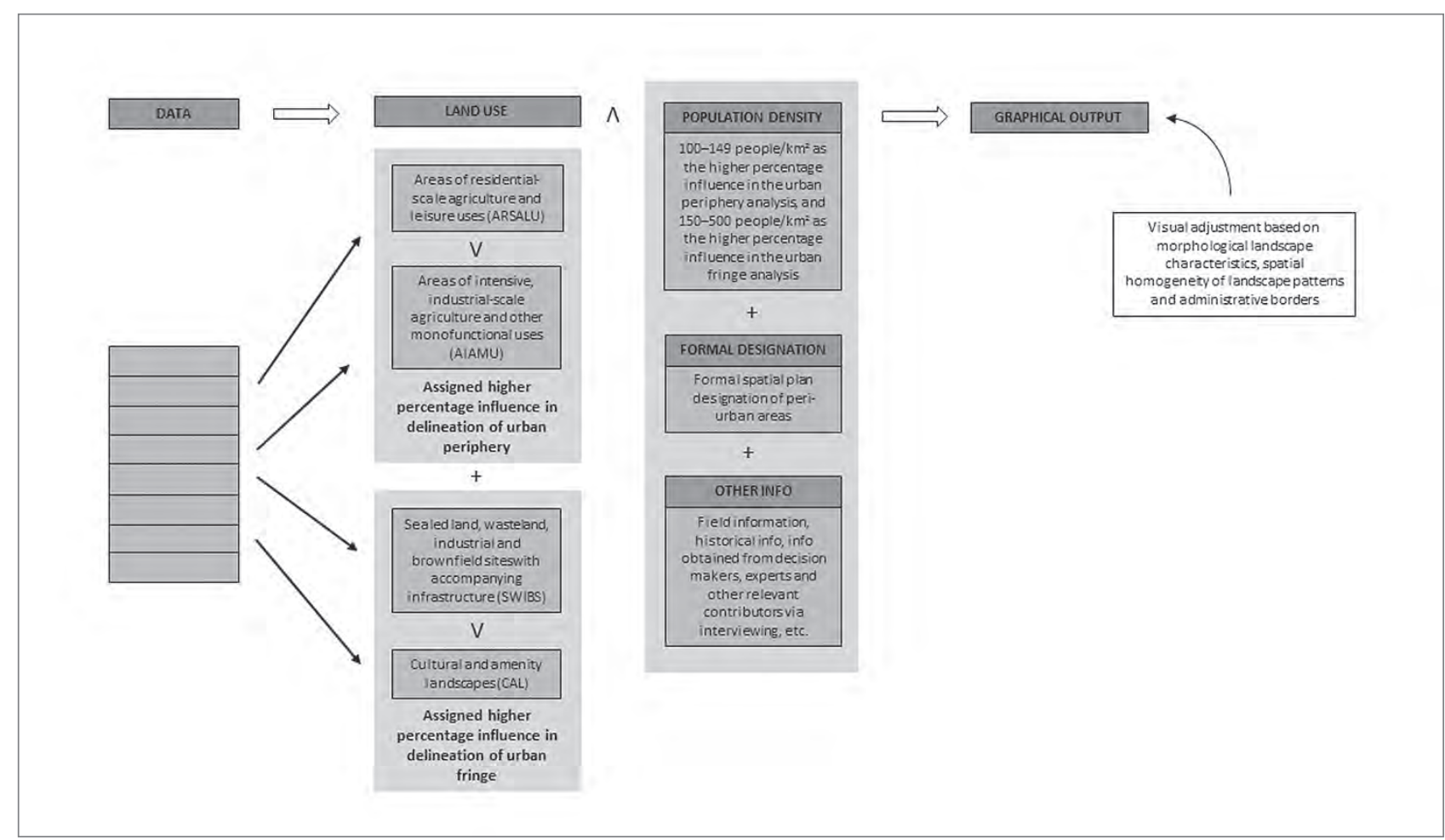

Figure 1: Graphic representation of peri-urban landscape delineation process (illustration: author).

value and use (Neuvonen et al., 2007; Qviström \& Saltzman, 2008; Žlender, 2021). The urban fringe is characterised by more urban uses such as transport hubs and settlements of higher density than the periphery, as well as elements like large green spaces. In contrast, the urban periphery is more influenced by the rural milieu, including lower-density settlements and agricultural uses (Piorr et al., 2011). Accordingly, the two land use types that incorporate agricultural characteristics (ARSALU and AIAMU) were assigned a higher percentage of influence in the analysis of urban periphery, and areas of predominantly natural and sealed land (SWIBS and CAL) were assigned a higher percentage of influence in the analysis of urban fringe. In deciding how to value the datasets, we also drew on complementary field information, historical information about the development of both cities, and interviews with local authorities and experts in urban planning, architecture, landscape architecture, infrastructure and other disciplines to improve the accuracy of our results (for more details, see other research outputs: Žlender, 2014, 2021; Žlender \& Ward Thompson, 2017; Žlender \& Gemin, 2020). This additional information was especially helpful in identifying the appropriate scale for delineation and in the final manual delineation of the urban core, urban fringe and urban periphery.

The next step overlaid the population density variable using the logical OR command, along with information on peri-urban areas as designated in local development plans and/or other formal documents. Based on the literature review, we determined the most discriminative population densities as two classes: $100-149$ people $/ \mathrm{km}^{2}$ as the higher percentage of influence in the urban periphery analysis, and 150-500 people/ $\mathrm{km}^{2}$ as the higher percentage of influence in the urban fringe analysis (Perpar, 2009; Piorr et al., 2011). We then intersected with the logical AND command the land use cluster with the output variable that resulted from merging the population density and peri-urban area datasets from the published spatial plans.

In the final delineation, we also considered morphological landscape characteristics and spatial homogeneity of landscape patterns as defined in Marušič et al. (1998). Figure 1 presents a flow diagram showing the procedure of combining data in peri-urban landscape delineation. The final outcome of this procedure are delineated areas of urban fringe and urban periphery as shown in Figures 3 and 6. The commentary in Section 4 details each step of the procedure and the final outcome for each case city.

\section{Results}

\subsection{Ljubljana}

Instances of AIAMU were very dispersed and fragmented, reflecting the spatial characteristics of Slovenia's agrarian structure (Cunder, 2002). The few instances of ARSALU were mainly located in the city, and most of these were allotments. Instances of SWIBS were dispersed, and the size of these plots 


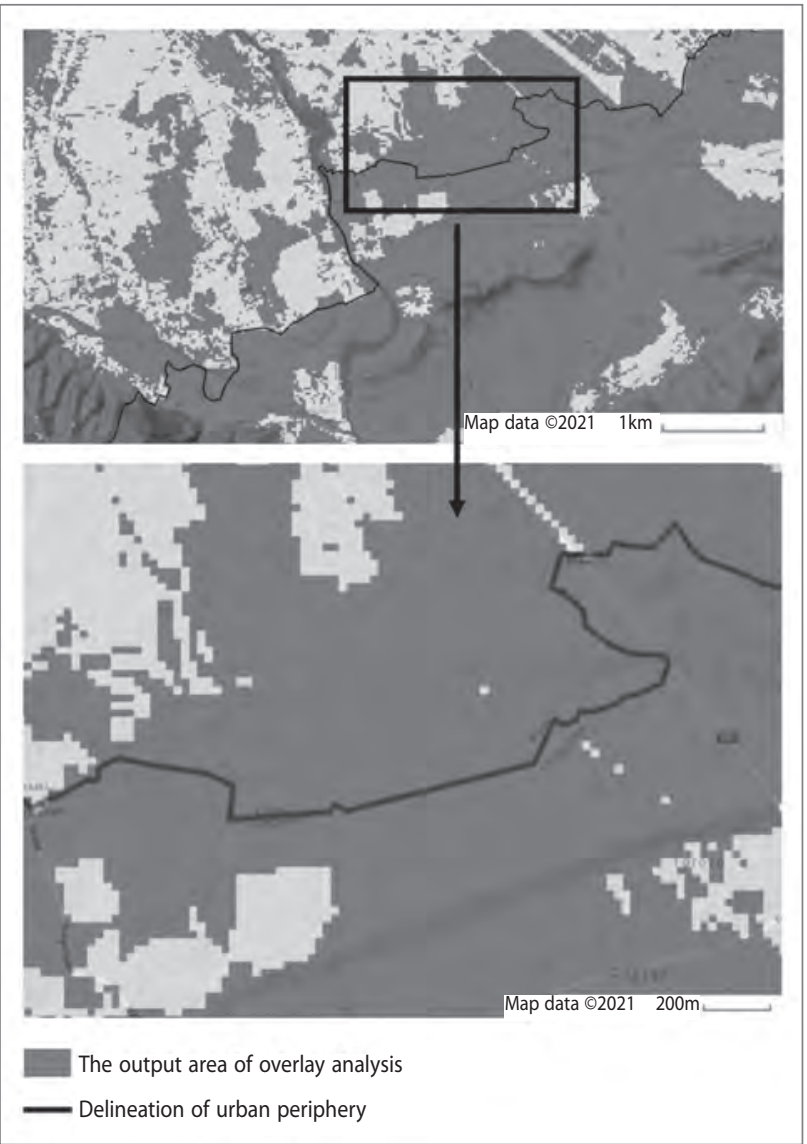

Figure 2: Close-up of the border of the urban periphery as delineated in Ljubljana (base map: ๑2021 Google).

Note: Parts of the border were manually aligned with administrative borders to facilitate further analysis.

suggests that these largely degraded areas were individual parcels of land, probably for private use. Larger areas were located on the edges of the city, indicating typical abandoned areas previously used for industrial purposes. Instances of CAL accounted for the largest area because the analysis included all forested land; for that reason, stricter criteria may be needed to prioritize some forest designations and/or exclude others. However, because urban dwellers favour nearby forest for recreational and leisure activities (Neuvonen et al., 2007), all forest designations were included in the analysis.

For the settlements included in Ljubljana and its environs, a raster of $1 \mathrm{~km}^{2}$ cells was used to measure densities of 100-149 people $/ \mathrm{km}^{2}$ and $150-500$ people $/ \mathrm{km}^{2}$ (SURS, 2019). The areas were rather dispersed and randomly located, and the results show no readily discernible pattern other than dense cores of satellite bedroom communities that have emerged in the vicinity of Ljubljana over the past few decades. One would expect to find more peri-urban densities in the eastern part of the municipality, where urbanization is more dispersed, but the analysis shows that this is still a predominantly rural area when population densities are taken into account.
In the final overlaid image (Figure 3), the city's core is clearly segregated, and the boundary between the urban area and urban fringe was readily definable. On the north side, the urban fringe's outer edge is defined by individual settlements within larger open spaces. On the south side, the presence of marshland makes the edge less definable. This instance of CAL extends from Ljubljana into the wider region. Based on this analysis, the peri-urban landscape on the south side of Ljubljana cannot be defined. To facilitate further analysis, artificial peri-urban borders were aligned with administrative borders (see Figure 2). This delineation may be appropriate at the regional scale but should be revisited at the local scale to enhance precision.

Here, the delineated urban fringe reflects the model outcome, corrected and refined to align with morphological barriers (streams and land-use borders) and built structures (roads and settlement edges). For this reason, it may coincide with administrative borders, which often follow natural borders. In places where the edge of the peri-urban landscape was close to existing administrative borders, these were deliberately aligned to facilitate further analytical work.

\subsection{Edinburgh}

Instances of AIAMU were located outside the city of Edinburgh; compared to Ljubljana, these were much larger spaces. Instances of ARSALU typically included gardens and allotments inside the city, indicating that gardening activities are popular in Edinburgh. According to Edinburgh's Allotment Strategy (CEC, 2017), the City of Edinburgh Council (CEC) manages 1,488 allotment plots at forty-four sites across the city. The city has adopted a strategic approach to address demand and to ensure that the benefits of allotment gardening are properly recognized and available to all (CEC, 2017). Accordingly, allotments are located as close as possible to people's homes rather than on the edges of the city. In contrast, although the number of allotments in Ljubljana is relatively high $(1,023)$, there are only nine sites (MOL, 2021; Figure 4). It should be noted that the backyards of Edinburgh flats, which were included in this category, are generally managed as grassy areas and not as allotments.

As in Ljubljana, SWIBS were scattered across the Edinburgh area, with larger areas concentrated on the west side of the city toward the airport. Pentland Hills Regional Park accounted for the largest proportion of CAL. On the south side, CAL extended into the city, linking the Braid Hills to the city's urban parks and semi-natural areas to form a green wedge connecting the city's core to its boundaries. 


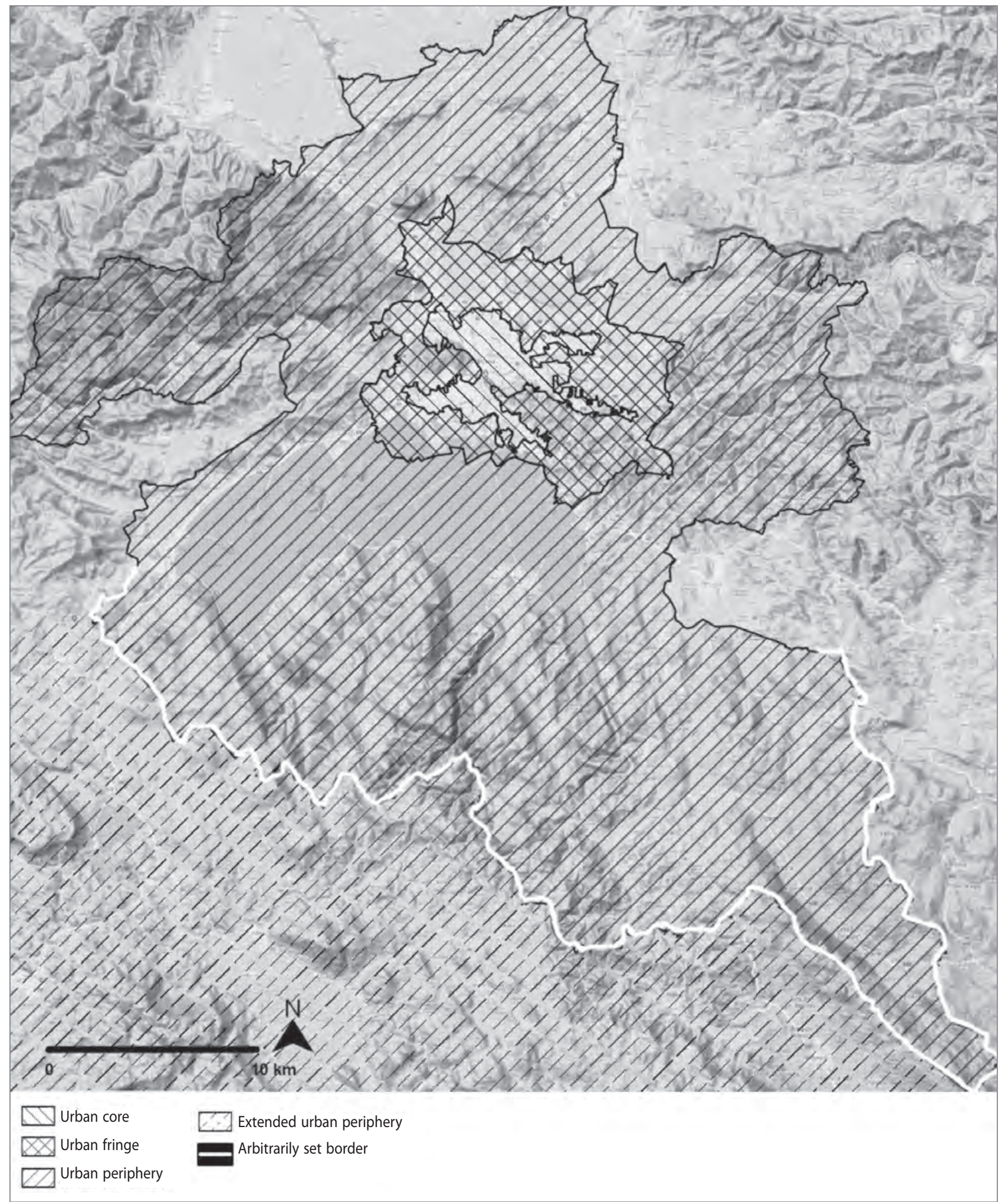

Figure 3: Peri-urban landscape of Ljubljana: outcome of the delineation process (base map: $₫ 2021$ Google).

In Edinburgh, population density was calculated using postcodes and included the Edinburgh City Council area and surrounding settlements (Internet 2). Because postcode areas can differ greatly in size, the dataset was complemented by Global Human Settlement Layer data, which is based on a $250 \mathrm{~m}^{2}$ cell
(European Commission, 2015). The resulting peri-urban densities coincided with the Green Belt and Countryside Policy areas, adding another layer to the delineation of the peri-urban landscape. Based on the overlay analysis, the inner edge of Edinburgh's urban fringe is marked by the Edinburgh City 


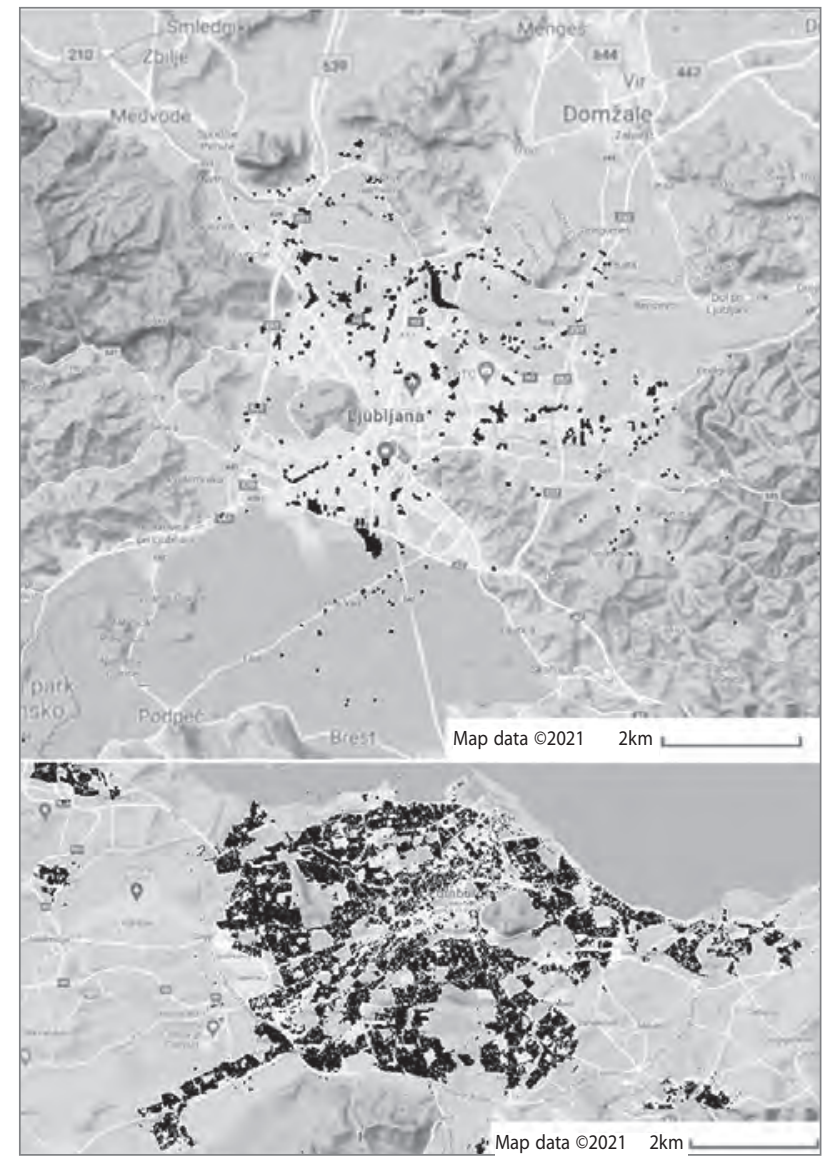

Figure 4: Excerpts showing input data for ARSALU in Ljubljana (top) and Edinburgh (bottom). (Source: Municipalities of Ljubljana, Medvode, Dobrova-Polhov Gradec, Brezovica, Ig, Škofljica, Grosuplje, Šmartno pri Litiji, Litija, Dol pri Ljubljani, Domžale, Trzin, Mengeš, and Vodice; CEC, Greenspace Scotland; base map: @2021 Google).

Bypass (Figure 5). On the southeast side, the edge no longer follows the bypass but extends into the city, encompassing the Braid Hills and an area on the city side of the bypass between Gilmerton and Musselburgh.

Edinburgh's urban fringe roughly corresponds to the area of the former Rural West Edinburgh Local Plan (CEC, 2006) and the Green Belt and Countryside Policy areas in the new Edinburgh Local Development Plan (CEC, 2016). Like the two previous plans, this includes policies and proposals to guide development and land use across Edinburgh. Beyond the stereotypical industrial sites, landfills, retail centres and green spaces, Edinburgh's urban fringe incorporates large predominantly agricultural areas governed by landscape policy. While urban fringes are generally perceived as low-value land use, Edinburgh's might instead be characterized as accessible countryside on the edge of the city. Nevertheless, there are also some typical fringe uses, including Edinburgh Airport, the Gyle shopping centre and the Heriot-Watt University campus. To the south and southeast, the urban periphery mainly consists of agricultural, forestry and recreational uses

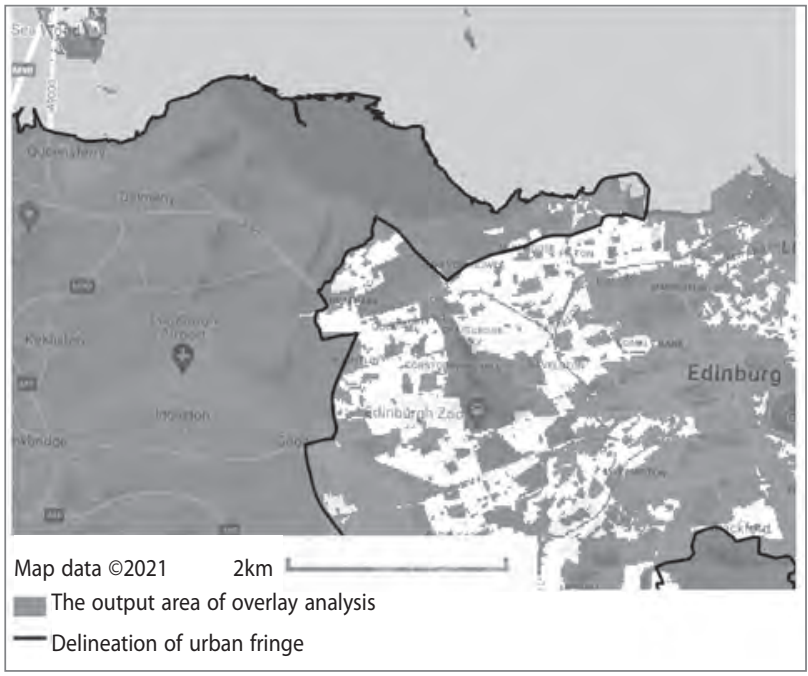

Figure 5: Close-up of the delineated border of Edinburgh's urban fringe (base map: @2021 Google).

Note: Parts of the border were manually aligned with the city bypass.

(e.g., Pentland Hills Regional Park, golf courses). With two distinct segments on the southwest and northwest sides, the periphery is not continuous, but land uses remain similar to those in the main peripheral area (Figure 6).

In this final representation of Edinburgh's peri-urban landscape, the urban core is well defined. Rather than stereotypical land uses, the peri-urban landscape can be characterized as accessible countryside. It also includes settlements, but these are more rural and self-contained in character than the peri-urban bedroom communities that were almost the rule in Ljubljana.

\section{Discussion}

\subsection{The importance of recognizing peri-urban landscape}

In general, our results support existing descriptions of peri-urban landscape in the literature. In Ljubljana, the peri-urban landscape includes a relatively narrow urban fringe and a large urban periphery characterized by semi-natural and natural areas that people value and use for recreation rather than industrial and other typical peri-urban land uses (Žlender \& Ward Thompson, 2017; Žlender, 2021). However, this area is located further from the city and is less easily accessible, for these activities, than the urban fringe. Interestingly, population density alone did not reveal any significant gradient from urban to rural in Ljubljana, unlike some other studies that emphasize this variable as a starting point (or the only one that matters) for analysis (see for example van Vliet et al., 2012; White et al., 2012; Wandl et al., 2014). The present findings suggest that an 


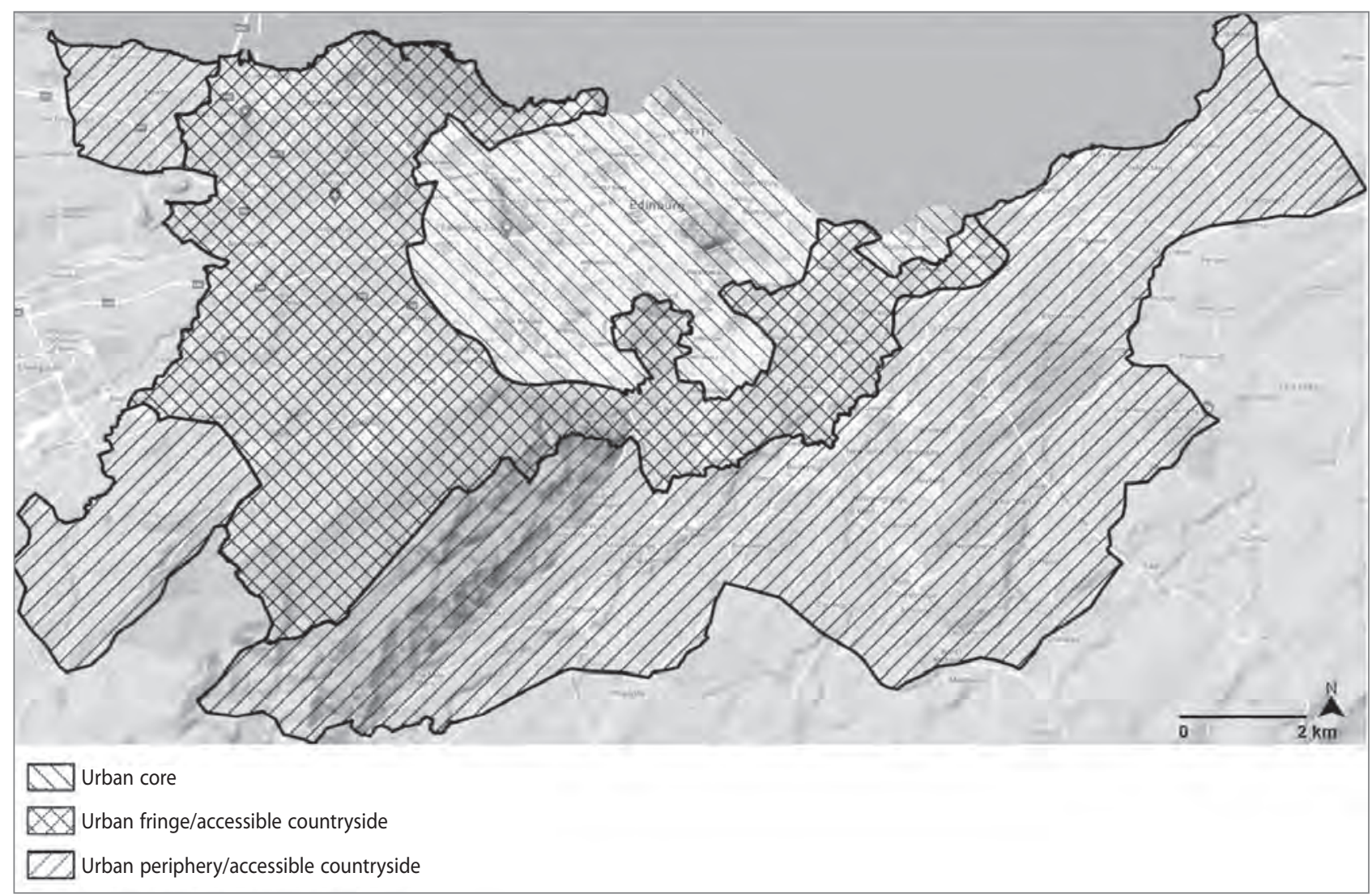

Figure 6: Delineation of Edinburgh's peri-urban landscape (base map: ๑2021 Google).

account of peri-urbanization based entirely on demographics cannot be generalized to other geographic settings.

In Edinburgh, the overlay analysis indicates an urban-rural dichotomy rather than a peri-urban landscape, which is also typical of UK cities in general (Bryant et al., 1982; Ambrose, 1992; Gallent et al., 2006). In this sense, it would be more appropriate to characterize these areas of Edinburgh as "accessible countryside". Indeed, the distinction between urban fringe and urban periphery may be largely irrelevant here, as land uses are very similar in both. This differs from Ljubljana, which is surrounded by multiple satellite settlements, with high levels of daily commuter traffic into and out of the city. While land uses in Ljubljana are less coherent than in Edinburgh, they are sufficiently differentiated to allow a clear distinction to be drawn between urban fringe and urban periphery.

\subsection{Directions for future planning and policy development}

The overlay analysis revealed that, although similar in size and population, the two case cities differ in spatial planning approach and in the existence and spatial extent of peri-urban landscape. Although these differences may relate to biophysical characteristics and purely operational decisions (such as choice of datasets), we contend that planning and policy decisions probably account for differences in urban growth (Hersperger et al., 2018; van Vliet et al., 2019). This is especially clear in Edinburgh, where a strict green belt strategy has prevented the city from spreading west and has increased densities within the urban envelope. However, the main purpose of the Edinburgh Green Belt is not to prevent the coalescence of settlements but to direct planned growth, protect landscape settings and ensure access to open space (CEC, 2016). This approach has remained largely unchanged since its introduction in 1957, although the new LDP has taken some areas out of the green belt, mostly to satisfy strategic housing requirements, possibly indicating the strategy's failure to counter the pressures of urbanization (Bunker \& Houston, 2003). The LDP controls the types of development allowed in the green belt and promotes opportunities to enhance countryside appearance and access (CEC, 2016). Along with the Countryside Policy, the Green Belt Policy defines in detail what development, if any, will be permitted in the interest of protecting landscape quality and/ or rural character. Despite evidence of the inadequacy of planning policies in combating urban encroachment (see for example Silva, 2019), the LDP draws a clear distinction between urban and rural areas and makes no mention of peri-urban landscape, urban fringe or other terms referring to the territory between rural and urban. Our analysis also confirmed that 
non-urban areas of Edinburgh are rural rather than peri-urban in character.

In Ljubljana, the OPN explicitly acknowledges peri-urban areas and defines basic criteria and guidelines for planning them. These provisions mainly pertain to the judicious use of space, promoting settlement concentration in existing built-up areas (infill and restoration) and mixed uses while preventing uncontrolled new construction. The OPN also provides for green spaces of different sizes and types and the future preservation of ecological and recreational assets. At the regional level, however, existing documents (both formally binding and non-binding) refer only generally or not at all to the peri-urban landscape (e.g., RRA LUR, 2020), let alone the goals and priorities of national-level legislation (e.g., Odlok o strategiji, 2004), which are deemed too broad and insufficiently quantified (MOP, 2016). It should be noted here that peri-urban areas are mentioned in the newly revised proposal for a national spatial development strategy (MOP, 2020), but this again fails to address the specifics of the peri-urban landscape.

As our analysis shows, peri-urban landscape may extend beyond municipal boundaries and should therefore be strategically addressed at sub-regional or regional level. Accordingly, there is a clear need to acknowledge peri-urban landscape in the future regional spatial plans as provided for in the state Spatial Management Act (ZUreP-2; Zakon o urejanju prostora, 2017). In this regard, the sub-regional to local level seems most appropriate for the adequate identification and handling of peri-urban areas in the relevant implementation documents. We argue that action plans based on smaller units (e.g., spatial planning units) are urgently needed to specify the existing and future state of individual peri-urban areas. Although we are conscious that the method described here is in need of further refinement, we believe it can assist legislators in defining peri-urban landscape and providing for its development and management.

Clearly, institutional differences of approach in managing rural-urban relationships can explain some of the variance in the extent and pattern of peri-urban development (Servillo \& Van Den Broeck, 2012). For now, the prevailing view is that current planning tools and policies fail to address the present state and drivers of peri-urban spatial development, and that plans based on an urban-rural dichotomy can only regulate urban and rural areas (Wandl et al., 2014; Bajracharya \& Hastings, 2018; Cattivelli, 2021a). With regard to scale, our analysis indicates that it is not enough to address peri-urban landscape issues in municipal plans. Instead, it is important to promote joint regulation of neighbouring areas with high levels of cross-sectoral cooperation in pursuit of integrated spatial planning and institutional governance (Nared et al., 2019; Cattivelli, 2021a;
Žlender, 2021). We are confident that the proposed approach can help to ensure more accurate characterization of peri-urban landscapes and thus improve the links between spatial planning and policy and the reality of development in these areas.

\subsection{Some critical reflections on the proposed method}

The method proposed here involves the detailed description and analysis of spatial data at the regional or sub-regional level. The selected case studies facilitated comparison of results, and the selected variables reflect land use and some sociodemographic aspects of the peri-urban landscape. Like any method, its utility depends on the context and objectives and is therefore subjective in nature. This is also true of the criteria for mapping the data, such as unit of population density or classes of nature preservation. Different criteria and classifications for data collection and merging would undoubtedly alter the delineation of the peri-urban landscape in both cases.

In addition, land use data do not always reflect functional or socioeconomic issues, and a major limitation of our method is the absence of other relevant data that are more difficult to map and therefore less commonly available as spatial datasets. Other relevant data would include the connecting and separating effects of infrastructure and elements that underpin the connectivity of places with different functions and intensities. These datasets would support more precise delineation of peri-urban landscape and, possibly, the particular characteristics of peri-urban sub-areas. As an attempt to shed light on territories that are neither urban or rural, we believe that the method described here is sufficiently flexible to accommodate additional datasets and different geographical settings. One important proviso is that adding further variables will inevitably increase the method's complexity, making it less attractive for potential users.

\section{Conclusion}

In this study, we described a spatial method for delineating peri-urban landscape that can be applied in different geographic settings and at different spatial scales. We argue that this spatially explicit approach can help to identify peri-urban areas and assess their quality, so enabling policy makers to optimize resources to facilitate spatially balanced and coherent urban growth while preserving peri-urban green spaces, which are currently neglected by planners and decision makers (Gant et al., 2011; Žlender \& Ward Thompson, 2017; Mortoja et al., 2020). This spatial delineation should be based on variables that reflect peri-urban land use as well as other relevant variables like population density. In the present case, we decided 
to use readily available datasets. To facilitate future peri-urban planning and policy formulation and for comparison of different spatial settings, the proposed method describes spatial characteristics as precisely as possible but is also applicable to other spatial settings. Clearly, the results would be improved and possibly altered by more and different data that are more accurate and by changing the thresholds that define classes. Nevertheless, we believe that this more explicit spatial framework serves as a useful starting point for scientific analysis and peri-urban policy development.

\section{Vita Žlender}

Urban Planning Institute of the Republic of Slovenia, Ljubljana, Slovenia

E-mail: vita.zlender@uirs.si

\section{Acknowledgements}

This article is based on doctoral research, which was funded by the Slovenian Human Resources Development and Scholarship Fund. The author also acknowledges financial support from the Slovenian Research Agency (research core funding no. P5-0100).

\section{References}

Adell, G. (1999) Theories and models of the peri-urban interface: A changing conceptual landscape. Research report. London, Development Planning Unit, UCL.

Ambrose, P. (1992) The rural/urban fringe as battleground. In: Short, B. (ed.) The English rural community: Image and analysis, pp. 175-194. Cambridge, Cambridge University Press.

Bajracharya, B. \& Hastings, P. (2018) A regional, strategic growth-management approach to urban and peri-urban development in south east Queensland, Australia. Journal of Regional and City Planning, 29(3), pp. 210-233. DOI: 10.5614/jrcp.2018.29.3.3

Bryant, C. R., Russwurm, L. \& McLellan, A. G. (1982) The city's countryside. Land and its management in the rural-urban fringe. London, Longman.

Bunker, R. \& Houston, P. (2003) Prospects for the rural-urban fringe in Australia: Observations from a brief history of the landscapes around Sydney and Adelaide. Australian Geographical studies, 41(3), pp. 303323. DOI: 10.1046/j.1467-8470.2003.00236.x

Cattivelli, V. (2021a) Planning peri-urban areas at regional level: The experience of Lombardy and Emilia-Romagna (Italy). Land Use Policy, 103(1-4), 105282. DOI: 10.1016/j.landusepol.2021.105282

Cattivelli, V. (2021b) Methods for the identification of urban, rural and peri-urban areas in Europe: An overview. Journal of Urban Regeneration \& Renewal, 14(3), pp. 240-246.

CEC (The City of Edinburgh Council) (2006) Rural West Edinburgh Local Plan. Edinburgh.

CEC (The City of Edinburgh Council) (2016) Edinburgh local development plan. Edinburgh.

CEC (The City of Edinburgh Council) (2017) Cultivation communities A growing success: The 3rd allotment strategy for the City of Edinburgh 2017-2027. Edinburgh.
Committee on Spatial Development (1999) European spatial development perspective (ESDP): Towards balanced and sustainable development in the territory of the European Union, agreed at the informal council of ministers responsible for spatial planning. Potsdam.

Couch, C., Petschel-Held, G. \& Leontidou, L. (2008) Urban sprawl in Europe: landscape, land-use change and policy. Chichester, John Wiley \& Sons. DOI: 10.1002/9780470692066

Council of Europe (2000) European Landscape Convention. Florence. Available at: https://www.coe.int/en/web/conventions/full-list?module=treaty-detail\&treatynum=176 (accessed 1 June 2021).

Cunder, T. (2002) Strukturne spremembe v slovenskem kmetijstvu in razvoj podeželja. Dela: podeželje na prelomu tisočletja: izzivi in problemi, 17, pp. 123-137. DOI: 10.4312/dela.17.123-137

Dadashpoor, H. \& Ahani, S. (2019) Land tenure-related conflicts in peri-urban areas: A review. Land Use Policy, 85, pp. 218-229. DOI: 10.1016/j.landusepol.2019.03.051

Dang, A., Yan, S. \& Liu, Y. (2000) GIS based study on the regionalization of China's grain production system. International Archives of Photogrammetry and Remote Sensing, 33(7), pp. 71-76.

Dijkstra, L. \& Poelman, H. (2010) Regional typologies overview - Statistics explained. Eurostat. Available at: http://epp.eurostat.ec.europa.eu/statistics_explained/index.php/Regional_typologies_overview (accessed 7 June 2021).

ESPON (European Spatial Planning Observation Network) (2005) ESPON 111: Potentials for polycentric development in Europe. Project report. Luxembourg.

ESRI (no date) ArcGIS ProArcGIS Pro. Available at: https://pro.arcgis.com/ en/pro-app/latest/tool-reference/spatial-analyst/overlay-analysis-approaches.htm (accessed 12 Aug. 2021)

EU (European Union) (2011). The EU biodiversity strategy to 2020. DOI: $10.2779 / 39229$

European Commission (2011) Communication from the Commission to the European Parliament, the Council, the European Economic and Social Committee and the Committee of the Regions Youth Opportunities Initiative. Brussels. Available at: https://eur-lex.europa.eu/legal-content/ $\mathrm{SL} / \mathrm{TXT} / \mathrm{PDF} /$ ?uri=CELEX:52011DC0933\&qid=1638787512432\&from=SL (accessed 10 Aug. 2021).

European Commission (2015) GHSL - Global Human Settlement Layer. Available at: https://ghsl.jrc.ec.europa.eu/visualisation.php\# (accessed 10 Aug. 2021).

Gallent, N., Andersson, J. \& Bianconi, M. (2006) Planning on the edge The context for planning at the rural-urban fringe. London, Routledge. DOI: $10.4324 / 9780203099193$

Gant, R. L., Robinson, G. M. \& Fazal, S. (2011) Land-use change in the "edgelands": Policies and pressures in London's rural-urban fringe. Land Use Policy, 28(1), pp. 266-279. DOI: 10.1016/j.landusepol.2010.06.007

Giffinger, R., Fertner, C., Kramar, H., Kalasek, R., Pichler-Milanović, N., Meijers, E., et al. (2007) Smart cities: Ranking of European medium-sized cities. Vienna, Vienna University of Technology, Centre of Regional Science.

Gonçalves, J., Gomes, M. C., Ezequiel, S., Moreira, F. \& Loupa-Ramos, I. (2017) Differentiating peri-urban areas: A transdisciplinary approach towards a typology. Land Use Policy, 63, pp. 331-341. DOI: 10.1016/j.landusepol.2017.01.041

Hersperger, A. M., Oliveira, E., Pagliarin, S., Palka, G., Verburg, P., Bolliger, J., et al. (2018) Urban land-use change: The role of strategic spatial planning. Global Environmental Change, 51, pp. 32-42.

DOI: 10.1016/j.gloenvcha.2018.05.001 
laquinta, D. L. \& Drescher, A. W. (2000) Defining the peri-urban: Rural-urban linkages and institutional connections. Land Reform, 2, pp. 8-27.

Inostroza, L., Baur, R. \& Csaplovics, E. (2013) Urban sprawl and fragmentation in Latin America: A dynamic quantification and characterization of spatial patterns. Journal of Environmental Management, 115, pp. 87-97. DOI: 10.1016/j.jenvman.2012.11.007

Internet 1: https://ec.europa.eu/eurostat/web/rural-development/methodology (accessed 5 May 2021).

Internet 2: https://www.scotlandscensus.gov.uk/search-the-census\#/ topics/location/PS?title=Postcode\%20(displayed\%20at\%200utput\%20 Area\%202011 (accessed 2 Jun. 2021).

Jacquin, A., Misakova, L. \& Gay, M. (2008) A hybrid object-based classification approach for mapping urban sprawl in periurban environment. Landscape and Urban Planning, 84(2), pp. 152-165.

DOI: 10.1016/j.landurbplan.2007.07.006

Korcelli, P. (2008) Review of typologies of European rural-urban regions. PLUREL D2.1.1.

La Rosa, D., Geneletti, D., Spyra, M., Albert, C. \& Fürst, C. (2018) Sustainable planning for peri-urban landscapes. In: Perera-Umas Peterson A. H., Pastur G. M. \& Iverson, L. (eds.) Ecosystem services from forest landscapes, pp. 89-126. Cham, Springer. DOI: 10.1007/978-3-319-74515-2_5

Maleas, I. (2018) Social housing in a suburban context: A bearer of peri-urban diversity? Urbani izziv, 29(1), pp. 73-82.

DOI: 10.5379/urbani-izziv-en-2018-29-01-002

Martyniuk-Pęczek, J., Martyniuk, O., Gierusz, A., in Pęczek, G. (2017) Determinants of SME location in a suburban area: Evidence from the Gdańsk-Gdynia-Sopot metropolitan area. Urbani izziv, 28(1), pp. 122134. DOI: 10.5379/urbani-izziv-en-2017-28-01-004

Marušič, J., Ogrin, D., Jančič, M., Bartol, B., Jug, M. \& Maligoj, T. (1998) Metodološke osnove: regionalna razdelitev krajinskih tipov v Sloveniji. Ljubljana, Ministrstvo za okolje in prostor RS, Urad RS za prostorsko planiranje.

Meeus, S. J. \& Gulinck, H. (2008) Semi-urban areas in landscape research: A review. Living Reviews in Landscape Research, 2(3), pp. 1-45. DOI: $10.12942 /$ /rrr-2008-3

MOL (Mestna občina Ljubljana) (2021) Urejanje vrtičkarskih območij. Available at: https://www.ljubljana.si/sl/moja-ljubljana/podezelje/ samooskrba-v-ljubljani/vrticki-v-ljubljani/urejanje-vrtickarskih-obmocij/ (accessed 24 May 2021).

MOP (Ministrstvo za okolje in prostor RS) (2016) Poročilo o prostorskem razvoju. Ljubljana, Ministrstvo za okolje in prostor, Direktorat za prostor, graditev in stanovanja.

MOP (Ministrstvo za okolje in prostor RS) (2020) Strategija prostorskega razvoja Slovenije 2050. Osnutek dokumenta v javni razpravi od 15. januarja 2020 do 15. marca 2020. Ljubljana.

Mortoja, M. G., Yigitcanlar, T. \& Mayere, S. (2020) What is the most suitable methodological approach to demarcate peri-urban areas? A systematic review of the literature. Land Use Policy, 95, 104601. DOI: 10.1016/j.landusepol.2020.104601

Nared, J., Hudoklin, J., Kavaš, D. \& Zavodnik Lamovšek, A. (2019) Povezovanje prostorskega in razvojnega načrtovanja na regionalni ravni v Sloveniji (= Georitem 29). Ljubljana, Založba ZRC. DOI: 10.3986/9789610501558

Neuvonen, M., Sievänen, T., Tönnes, S. \& Koskela, T. (2007) Access to green areas and the frequency of visits - A case study in Helsinki. Urban Forestry \& Urban Greening, 6(4), pp. 235-247.

DOI: 10.1016/j.ufug.2007.05.003
Odlok o občinskem prostorskem načrtu Mestne občine Ljubljana - strateški del. Uradni list Republike Slovenije, no. 78/2010. Ljubljana.

Odlok o strategiji prostorskega razvoja Slovenije. Uradni list Republike Slovenije, no. 76/2004. Ljubljana.

OECD (2010) OECD Regional Typology. Paris, Directorate for Public Governance and Territorial Development.

ONIX (2000) ProVal 2000 v1.1. Realis d.o.o., Dioptra, d.o.o., MOP-GIC.

Perpar, A. (2009) Analysis of regional spatial planning and decision-making strategies and their impact on land use in the urban fringe - case study KOPER. Ljubljana, Biotechnical Faculty, Department of Agriculture.

Piorr, A., Ravetz, J. \& Tosics, I. (2011) Peri-urbanisation in Europe: Towards a European Policy to sustain Urban-Rural Futures. Copenhagen, University of Copenhagen / Academic Books Life Sciences.

Qviström, M. \& Saltzman, K. (2008) Ambiguous edgelands: Landscape studies beyond rural-urban divides and disciplinary trench-lines. Urban Forestry \& Urban Greening, 7(3), pp. 143-144. DOI: 10.1016/j.ufug.2008.06.001

Rauws, W. \& de Roo, G. (2011) Exploring transitions in the peri-urban area. Planning Theory \& Practice, 12(2), pp. 269-284. DOI: $10.1080 / 14649357.2011 .581025$

RRA LUR (2020) Regionalni razvojni program Ljubljanske urbane regije 2021-2027: 1. osnutek. Ljubljana, Regionalna razvojna agencija Ljubljanske urbane regije.

Servillo, L. A. \& Van Den Broeck, P. (2012) The social construction of planning systems: A strategic-relational institutionalist approach. Planning Practice and Research, 27(1), pp. 41-61.

DOI: $10.1080 / 02697459.2012 .661179$

Shaw, B. J., van Vliet, J. \& Verburg, P. H. (2020) The peri-urbanization of Europe: A systematic review of a multifaceted process. Landscape and Urban Planning, 196, 103733. DOI: 10.1016/j.landurbplan.2019.103733

Silva, C. (2019) Auckland's urban sprawl, policy ambiguities and the peri-urbanisation to Pukekohe. Urban Science, 3(1), p. 1. DOI: 10.3390/urbansci3010001

Stahlschmidt, P., Swaffield, S., Primdahl, J. \& Nellemann, V. (2017) Landscape analysis: Investigating the potentials of space and place. London, Routledge. DOI: 10.4324/9781315682792

SURS (Statistični urad Republike Slovenije) (2019) Population Available at: https://gis.stat.si/ (accessed 1 Jun. 2021).

Swanwick, C. (2002) Landscape character assessment: Guidance for England and Scotland. Cheltenham, UK, Countryside Agency and Scottish Natural Heritage.

Unwin, T. (1989) Urban-rural interaction in developing countries: A theoretical perspective. The Geography of Urban-Rural Interaction in Developing Countries, pp. 11-33, London, Routledge. DOI: 10.4324/9781351215381-1

van Vliet, J., Hurkens, J., White, R. \& van Delden, H. (2012) An activity-based cellular automaton model to simulate land-use dynamics. Environment and Planning B: Planning and Design, 39(2), pp. 198-212. DOI: 10.1068/b36015

van Vliet, J., Verburg, P. H., Grădinaru, S. R. \& Hersperger, A. M. (2019) Beyond the urban-rural dichotomy: Towards a more nuanced analysis of changes in built-up land. Computers, Environment and Urban Systems, 74, pp. 41-49. DOI: 10.1016/j.compenvurbsys.2018.12.002

Wandl, D. A., Nadin, V., Zonneveld, W. \& Rooij, R. (2014) Beyond urban-rural classifications: Characterising and mapping territories-in-between across Europe. Landscape and Urban Planning, 130, pp. 50-63. DOI: 10.1016/j.landurbplan.2014.06.010 
White, R., Uljee, I. \& Engelen, G. (2012) Integrated modelling of population, employment and land-use change with a multiple activity-based variable grid cellular automaton. International Journal of Geographical Information Science, 26(7), pp. 1251-1280.

DOI: 10.1080/13658816.2011.635146

Zakon o urejanju prostora (ZUreP-2). Uradni list Republike Slovenije, no. 61/17. Ljubljana.

Žlender, V. (2014) Open space on the edge of the city: Exploring how people's perceptions and usage can inform management of peri-urban open spaces, focusing on case studies of Ljubljana and Edinburgh. Edinburgh, University of Edinburgh.

Žlender, V. (2021) Characterisation of peri-urban landscape based on the views and attitudes of different actors. Land Use Policy, 101, 105181. DOI: 10.1016/j.landusepol.2020.105181

Žlender, V. \& Gemin, S. (2020) Testing urban dwellers' sense of place towards leisure and recreational peri-urban green open spaces in two European cities. Cities, 98, 102579. DOI: 10.1016/j.cities.2019.102579

Žlender, V. \& Ward Thompson, C. (2017) Accessibility and use of peri-urban green space for inner-city dwellers: A comparative study. Landscape and Urban Planning, 165, pp. 193-205.

DOI: 10.1016/j.landurbplan.2016.06.011 